\title{
Economic Analysis of Production Systems of Small Farmers that Adopt "Bacurizeiro" Management in Pará State, Brazilian Amazon
}

\author{
Ercilene de Cássia Ferreira Rodrigues
}

Federal University of Pará (UFPA), Master's degree in Family Farming and Sustainable Development, Belém, PA, Brazil. E-mail: cassiaferreira76@yahoo.com.br

\begin{abstract}
Alfredo Kingo Oyama Homma
Brazilian Agricultural Research Corporation (Embrapa) and professor of the Post-graduate Program in Environmental Sciences (PPGCA/UEPA), Belém, PA, Brazil. E-mail: alfredo.homma@embrapa.br
\end{abstract}

\begin{abstract}
Osvaldo Ryohei Kato
Brazilian Agricultural Research Corporation (Embrapa) and professor of the Post-graduate Program in Amazon Agriculture (PPGAA/UFPA), Belém, PA, Brazil.

E-mail: osvaldo.kato@embrapa.br
\end{abstract}

Antônio José Elias Amorim de Menezes

Brazilian Agricultural Research Corporation (Embrapa), Belém, PA, Brazil.

E-mail: antonio.menezes@embrapa.br

Fabrício Khoury Rebello

Federal Rural University of Amazon (UFRA), professor of the Post-graduate Program in Agronomy (PGAGRO/UFRA), Belém, PA, Brazil. E-mail: fabricio.rebello@ufra.edu.br

Received: May 9, 2020

doi:10.5296/jas.v8i4.17386
Accepted: July 12, 2020 Published: July 20, 2020

URL: https://doi.org/10.5296/jas.v8i4.17386 


\section{Abstract}

Platonia insignis Mart., known as "bacurizeiro", is a medium to large tree species whose fruit (called "bacuri"), wood and energy are used for many purposes. Its origin center is in the Eastern Amazon. This paper carries out an economic analysis of the production systems management performed by small producers that manage bacurizeiro in natural occurrence areas in Brazilian Amazon, highlighting aspects of their importance for the social reproduction strategy of small farmers. The management is understood as an improving process of the simple extractivism of collect, seeking to increase the land and labor productivity, increasing the density or creating more favorable conditions for bacurizeiro. In order to perform the field survey, an intentional sampling was chosen, considering only the small farmers who had bacurizeiro in their establishments and who commercialized their products to limited degree. A total of 77 questionnaires were applied among the 7 assessed municipalities, which 57 were in the Northeastern Para Mesoregion and 20 in Marajó, conducted from November 2016 to March 2017. A typology of production systems was carried out, where four types were found: bacurizeiro and small farming, bacurizeiro and fruit orchard, bacurizeiro and fishing and bacurizeiro and social security. It was found that the production systems with the highest degree of species diversification possess the highest potential of income generation besides the highest agricultural income and the highest small farmers income. Those are the production systems belonging to bacurizeiro and fruit orchard (T2). Bacurizeiro significantly contributes to all types of production systems found, representing a minimum average participation in agricultural income of $19.99 \%$ (bacurizeiro and fishing). The sale of fruits and pulp of represents an essential social reproduction strategy to small producers in Northeastern of Pará and in Marajó.

Keywords: family farming, rural economy, farm income, Platonia insignis Mart

\section{Introduction}

Platonia insignis Mart., known as "bacurizeiro", is a medium to large tree species whose fruits (called "bacuri"), wood and energy can be exploited. Its origin center is in the Eastern Amazon. They occur spontaneously in all the states of the North Region and in Mato Grosso, Maranhão and Piauí. It is also found in Guiana, Peru, Bolivia, Colombia, and Ecuador (Menezes, 2012).

In primary vegetation ecosystems, the bacurizeiro occurs in clusters of five to seven plants. However, when considering the entire occurrence area, the bacurizeiro density per hectare is very low, less than one plant per hectare, as is the case with most tree species in the Amazon Rainforest (Ferreira, 2008; Menezes, 2010). Bacurizeiro has a unique feature of resprouting from its roots. The resprouting is a physiological mechanism of some plant species; besides, regarding bacurizeiro, the sun light has a positive effect. Therefore, in the old occurrence areas of bacurizeiro, it is verified the resprout of this species, as if it were a weed, in the struggle for survival (Medina \& Ferreira, 2003).

Many producers transform these sprouts that are born spontaneously by managing them, arranging them in an appropriate spacing, controlling the crowns, shoots and invasive herbs, 
allowing the formation of bacurizeiro woods and, thus, creating alternatives for degraded areas of Northeastern Pará and Marajó mesoregions. Due to the ease of resprouting, bacurizeiro can also be recommended for reforestation, with the aim of firewood, charcoal and wood production, without requiring seedling production and more delicate cultural treatments (Matos, 2008).

Bacurizeiro can be managed from the root sprouts, in the prepared and then, abandoned areas for crops. The fruit production occurs if the fruits are prevented from future felling and from fire entrance, in an eight-ten year period in the secondary forest. Because of the fruit market growth, this rustic plant began to receive more attention from small producers. The management favors this species in areas usually close to residences, such as backyards. The management consists of promoting the most vigorous sprouts, leaving a random spacing that varies from 4 to $8 \mathrm{~m}$ between the individuals in the abandoned fields. The posterior care refers to annual weeding when adults, facilitating the fruits collection (Matos, 2008; Menezes, 2010).

It assumes economic importance in the states of Pará, Maranhão, Tocantins, and Piauí, where dense and diversified natural populations are concentrated in areas of secondary vegetation, where Pará is the leading producer and consumer of fruit and pulp of bacurizeiro (Menezes et al., 2016). The bacuri, fruit of the bacurizeiro is primarily demanded in the local market, and its demand for export has grown (Homma et al. 2018). Consequently, many families have noticed ways to anticipate the production, as the bacurizeiro begins to produce in approximately ten years.

The management is understood as an improving process of the simple harvest extractivism, whose objective is to increase the productivity of land and labor, through the increase in the density or creating more favorable conditions for bacurizeiro (Menezes, 2010). Recently, research institutions have sought to know and to stimulate the bacurizeiro management from technical premises for the cultivation. The management techniques, recommended by Eastern Amazon Embrapa, consists of thinning by selecting the most vigorous shoots that grow in abandoned fields. The approximate spacing is $10 \mathrm{~m} \times 10 \mathrm{~m}$, so annual crops can be performed between the lines in the first years, leading to reduce the implantation costs and the sowing of perennial plants, forming agroforestry systems (Ferreira, 2008; Menezes et al., 2012).

Once this paper studies the farming families, it is important to understand the strategies adopted, challenges faced and the tools available to keep on producing, giving emphasis to bacurizeiro management as a complement income alternative.

The relations in agriculture, as well as the social reproduction, are dynamic processes, affected by local specificities, creating heterogeneity of social contexts. This heterogeneity is consequence of many constant transformations and adaptations regarding properties, previous experiences and external context, that influence decision-making by specific strategies in the production unit, considering if the way of managing family is more integrated to the market or more independent (REDIN, 2012).

The objectives of this paper are to carry out an economic analysis of production systems 
performed by small producers that manage bacurizeiro and to discuss their importance to family management and livelihood. The article begins by proposing the elements for analysis (bacurizeiro management and production system), going on to the brief description of the production systems types found in the study and, later, to the discussion of the financial results obtained by the combinations of farming productive activities and non-agricultural incomes, considering the organizational strategies of small farmers establishments.

\section{Methods}

\subsection{Study Area and Data Source}

The mesoregions of the Northeastern Pará and Marajó as a study area were chosen based on the current information that they are producing areas that account for the largest supply of bacurizeiro fruits in Brazilian Amazon. According to Cavalcante (1991), the area with the highest concentration of bacurizeiro is the Amazon River estuary, with a more pronounced occurrence in the Salgado microregion, in some municipalities of the Bragantina microregion and in the Marajó mesoregion, in Pará state, located in Brazilian Amazon, which is composed of nine Units of the Brazilian Federation. In the mesoregion of Northeastern Pará, the surveys were carried out with families from the municipalities of Bragança, Tracuateua and Augusto Corrêa, in Bragantina microregion, and from the municipality of Maracanã, part of the Salgado micro-region. In Marajó, information was collected in the municipalities of Cachoeira do Arari, Salvaterra, and Soure, located in the Arari microregion.

The methodological procedures were based on qualitative and quantitative approaches. Brumer et al. (2008) point out that in the quantitative approach, it is possible to generalize the results for similar groups and in the qualitative approach, one examines in depth the qualities of a phenomenon. The quantitative approach was conducted in order to generalize the production system types per municipality, and the qualitative approach was performed to understand the motivations and transformations that occurred within the most representative production system of each type found in here.

The survey relied on both primary and secondary data. The secondary data that came from different sources, served as support to know the local economy of the studied municipalities. The primary data were obtained through questionnaires.

In order to carry out the field survey, an intentional sampling was chosen, considering only the small producers who own bacurizeiro in their farms and who commercialize some of the products. According to Marconi \& Lakatos (1996), the intentional sample is the most common among those considered non-probabilistic and therefore does not allow generalizations of the results, but it is valid, within a specific context, to support secondary data interpretations, aiming at characterizing the bacurizeiro management systems developed by small producers.

The small producers were interviewed following the snowball (Vinuto, 2014) methodological technique, which is a non-probabilistic sample form used in surveys where the first participants of a study indicate new participants that in turn indicate new participants among others until the proposed goal is achieved. According to Vinuto (2014), this technique is a 
useful net sampling method to study populations that are hard to be accessed or studied or that there is no precision about their quantity. In the case of bacurizeiro, there is no available data in the official country statistics, since it is constituted of a product that belongs to invisible economy (Menezes, 2010).

The study was conducted with 77 producers in two natural occurrence areas of bacurizeiro, 57 in the Northeastern Pará Region and 20 in the Marajó, through an intentional sample, carried out from november 2016 to march 2017. The use of the intentional sample resulted from the difficulty of using probabilistic sampling due to the dispersion of small producers and the cost of the survey.

The questionnaire approached general topics about family and establishment as well as it focused on the bacurizeiro management and their relation with other farming activities. The following were analyzed: informant identification (name, place of birth, job, age); family composition (number of people, age, if they work outside the property, the kind of work); bacurizeiro production aspects (general information on the trees characteristic, fruit harvest, fruit type, fruit pulp processing, commercialization); landholding situation; property structure; land use (forest area size, crop area size, etc.) and family income composition. Family income is the sum of the farming and the non-farming income.

This research was based on the methodology of Agrarian Systems Diagnostic Analysis, proposed by Garcia Filho (1999) since the methods allowed to identify and characterize the production system of the evaluated areas.

After the data systematization obtained through the questionnaires, a typology of the production systems was performed, to facilitate a more detailed understanding of the different productive arrangements. According to Garcia Filho (1999), the typology allows the producers to be grouped into distinct groups that are similar to each other. The main criterion for performing the typology was the family income source.

\subsection{Economic Analysis}

As the economic analysis was developed, we tried to analyze and compare the income of the farmers that manage bacurizeiro by taking into account the identified typologies. According to Garcia Filho (1999), the economic evaluation allows more depth studies on the social relations that characterize each type of production unit and the agrarian system as a whole. To that end, it was evaluated the added value, which is the addition of work to inputs and to the fixed capital available, generating new wealth and adding value to these goods.

Added Value (AV), through the following equation (Garcia Filho, 1999):

$$
\mathrm{AV}=\mathrm{GP}-\mathrm{IC}-\mathrm{D}
$$

Where:

GP $=$ Gross Product, which corresponds to the total value of what is produced, either for sale or for consumption by the family;

$\mathrm{IC}=$ Intermediate Consumption, which are the inputs that the producer used to produce 
(fertilizers, equipment rental, among others); For costs calculation, a discount of $30 \%$ of the total gross product of the establishments was considered, taking into account the diversity related to each production unit;

$\mathrm{D}=$ Depreciation, which corresponds to the wear and tear of the goods as a function of the use time (machinery, shed, among others) that the producer used during the production process. For calculation, it was used the depreciation of machetes, hoe and brushcutter equipment, with a 10-year useful life and prices applied in 2017 of $50 \mathrm{BRL}, 100 \mathrm{BRL}$ and 2.000 BRL,respectively.

Farm Income (FI), which is the income obtained from all and any products derived from agricultural production. The production batch was estimated using the following equation:

$$
\mathrm{FI}=\mathrm{AV}-\mathrm{W}-\mathrm{T}-\mathrm{I}-\mathrm{LR}
$$

Where:

$\mathrm{W}=$ Wages, in case of hiring of labor;

$\mathrm{T}=$ Taxes, a charge paid to the government to have the right to produce;

$\mathrm{I}=$ Interest, the rate paid by the producer in return for the loans granted by the banks;

LR $=$ Land Rent (land leasing).

The Simple Reproduction Level (SRL) is the minimum income needed to generate the means of unit production and remunerate family labor over time. The SRL was estimated as an indicator of the opportunity cost of work, calculated through the minimum wage per Man Work Unit (MWU). The total economic performance of each type of production system found in the study was related to the expected reproduction level. The measure of the financial result that evaluates the system performance is the Farm Income, and the indicator of the SRL is the equivalent value of a monthly minimum wage per worker (minimum wage / MWU) during the year. The minimum wage used was 937.00 BRL per month, effective in 2017.

Thus, the SRL is given by the following formula:

$$
\mathrm{SRL}=\mathrm{W} \times \mathrm{MWU} / \mathrm{year}
$$

Where:

$\mathrm{W}=$ current minimum wage.

\section{Results}

\subsection{Production Systems Found in the Study}

In order to achieve this typology, the production systems were grouped into distinct types, but expressing some similarity among each other. It happens because each family has its own socioeconomic background and performs their family strategies in different ways, not adopting the same production system or using the available natural resources in the same 
way.

In order to understand which productive activities are practiced in the production systems and how bacurizeiro is related to this set of activities, the systematization of data obtained through the questionnaires was provided. It was verified that the most significant criteria to carry out the differentiation of the systems are the origin of family income and the relation with bacurizeiro management.

Therefore, based on the studied reality, four production systems types were obtained, namely: Type 1: Bacurizeiro and Crop; Type 2: Bacurizeiro and Fruit Trees; Type 3: Bacurizeiro and Fisheries; and, Type 4: based on government transfers. This typification is shown in Table 1.

Bacurizeiro only produce fruits in periods of up to four months of harvest and; therefore, although some producers inform that their primary source of income is generated by the commercialization of fruits or pulp of bacurizeiro, it is known that this crop would not be able to maintain the families' livelihoods throughout the year. Consequently, it was considered the interaction between areas with bacurizeiro and other activities that generate income to carry out this typology.

In order to perform the typology, the total of 77 families were interviewed. Among these, 59 families, that is, $76.6 \%$, were identified as Type 1 - Bacurizeiro and crop. In Northeastern Pará, crop deals exclusively with cassava cultivation, with flour production for sale and consumption and in some cases for roots sale. In Marajó, the families consider the pineapple cultivation, in addition to the cassava production.

Out of the total number of interviews, $7.8 \%$ of families represent Type 2, characterized by the bacuri fruit and pulp commercialization and other fruit trees, which the main ones are acai (Euterpe oleracea), coconut (Cocos nucifera), banana (Musa spp), passionflower (Passiflora edulis Sims) and others.

Table 1. Specifications on the production systems types performed by the farmers in mesoregions of the Northeastern Pará and Marajó

\begin{tabular}{|c|c|c|c|c|}
\hline Types & 1 & 2 & 3 & 4 \\
\hline Description & $\begin{array}{l}\text { Bacurizeiro and } \\
\text { small crops }\end{array}$ & $\begin{array}{c}\text { Bacurizeiro } \\
\text { and Fruit trees }\end{array}$ & $\begin{array}{l}\text { Bacurizeiro and } \\
\text { Fishing }\end{array}$ & $\begin{array}{ll}\text { Based } & \text { on } \\
\text { Government } & \\
\text { Transfers } & \end{array}$ \\
\hline $\begin{array}{l}\text { Number of } \\
\text { families / } \\
\text { establishments }\end{array}$ & $76.6 \%$ & $7.8 \%$ & $11.7 \%$ & $3.9 \%$ \\
\hline $\begin{array}{l}\text { Primary Income } \\
\text { Source }\end{array}$ & Small crop & Fruit trees & Fishing & Social Security \\
\hline Characteristics & $\begin{array}{c}\text { Areas with } \\
\text { bacurizeiros, } \\
\text { cassava crop, } \\
\text { pineapple crop } \\
\text { (Marajó) }\end{array}$ & $\begin{array}{c}\text { Areas with } \\
\text { bacurizeiros } \\
\text { associated with } \\
\text { SAFs }\end{array}$ & $\begin{array}{c}\text { Areas with } \\
\text { bacurizeiros and } \\
\text { producers } \\
\text { licensed as } \\
\text { Fishermen }\end{array}$ & $\begin{array}{c}\text { Areas with } \\
\text { bacurizeiros } \\
\text { associated with } \\
\text { other backyard } \\
\text { fruit trees. }\end{array}$ \\
\hline
\end{tabular}


Families who have fishing as a regular profession characterize Type 3, and this type was found only in Marajó. It is noteworthy that although these families are grouped in another production system type, many of them also practice the cultivation of both cassava and pineapple to perform the maintenance and subsistence of their establishments.

Type 4 is characterized by families that do not have agricultural activities and have, as the sole source of income, the retirement or benefit with a minimum wage. These families have the maximum of two members with an average age above 60 years old.

Of the 77 families, $72.7 \%$ are leaving new areas with bacurizeiro for management (56 families). The estimation of $73 \%$ of the total number of families interviewed has areas with bacurizeiro regrowth. It indicates the increasing interest of families to manage due to market growth, as Menezes (2010) had also observed in his thesis.

Among the 59 families of Type 1, 42 have regrowth areas, found in secondary vegetation or in clean areas. The size of the most representative area is up to one hectare, representing 59\% of the total families interviewed, followed by areas with up to 5 hectares, representing $24 \%$ as shown in Table 2.

Among families of Type 2, all have areas for regrowth, and all establishments have areas of up to one hectare (Table 2).

Of the 9 families representing Type 3, 6 families, that is, 67\% have areas of bacurizeiro resprout, $50 \%$ of these establishments have areas of up to one hectare, and $50 \%$ have areas over 1 hectare and less than 5 hectares (Table 2).

Of the 3 families of Type 4, 2 families have areas of bacurizeiro resprout, and of this total, all the areas have the maximum of one hectare, as it appears in Table 2.

Table 2. Size of resprouting areas and frequency per production system type found among the families interviewed

\begin{tabular}{ccccccccc}
\hline $\begin{array}{c}\text { Size of the } \\
\text { area (ha) }\end{array}$ & Type 1 & $\%$ & Type 2 & $\%$ & Type 3 & $\%$ & Type 4 & $\%$ \\
\hline Up to 1 & 25 & 59 & 6 & 100 & 3 & 50 & 2 & 100 \\
from 1.1 to 5 & 10 & 24 & 0 & 0 & 3 & 50 & 0 & 0 \\
from 5.1 to 10 & 2 & 5 & 0 & 0 & 0 & 0 & 0 & 0 \\
$>10$ & 5 & 12 & 0 & 0 & 0 & 0 & 0 & 0 \\
\hline Total & 42 & 100 & 6 & 100 & 6 & 100 & 2 & 100 \\
\hline
\end{tabular}

The representative labor force in Type 1 and Type 2 systems is the family and hired labor, which is equivalent to $63 \%$ and $67 \%$ of the families interviewed (Table 3), respectively. The 
main activities that require hiring people are cleaning and cutting the area (including bacurizeiro management) and the harvest of both cassava and pineapple. The labor values practiced in the studied municipalities ranged from 30.00BRL to 40.00BRL depending on the agricultural activity, with work hours ranging from 8 to 12 o'clock. In Marajó, the labor hired for pineapple harvest activity is 5.00BRL per line harvested, with work hours from 6 to 9 o'clock.

The Type 3 representative labor is family labor, representing $66 \%$ of the families interviewed. The exclusively hired labor was only found in Type 4, where all the families were composed of two people of high age, who declared themselves tired for farming activity. It is noteworthy that in this group, the hired activities were mainly related to the maintenance of the cleaning area. Also, one of the families hired labor for fruit harvest, practicing the value of 10.00BRL to 20.00BRL in the daily labor depending on the amount of harvested fruits.

Table 3. Labor types and frequency per production system type found among the interviewed families in Northeastern Pará and Marajó mesoregions

\begin{tabular}{ccccccccc}
\hline Labor & Type 1 & $\%$ & Type 2 & $\%$ & Type 3 & $\%$ & Type 4 & $\%$ \\
\hline Family & 22 & 37 & 2 & 33 & 6 & 67 & 0 & 0 \\
Family and Hired & 37 & 63 & 4 & 67 & 3 & 33 & 0 & 0 \\
Hired & 0 & 0 & 0 & 0 & 0 & 0 & 3 & 100 \\
\hline Total & 59 & 100 & 6 & 100 & 9 & 100 & 3 & 100 \\
\hline
\end{tabular}

\subsection{Economic Evaluation}

The production systems practiced by small farmers in Pará Amazon have different capacities to generate new wealth. Consequently, reach different levels of economic profitability. According to the technical and investment characteristics of the families, each system presents expected economic returns.

The systems ability to generate new wealth can be expressed by the Added Value (AV), where it is possible to quantify the net production of the establishment in the year and the profitability evaluated by the farm income.

It was found that the production systems with the highest degree of species diversification have greater potential of income generation. Moreover, they are those that have the highest agricultural income and the highest family income. These are the production systems that belong to the bacurizeiro and fruit trees group (T2), which reached an added value of 23,140.33BRL/year (Table 3). This is justified since these families are organized both in the production of seasonal fruit pulp, such as bacuri, açai and others, as well as in fruits that maintain production throughout the year, such as passion fruit and cupuaçu. These fruits aim at the sale of processed products that adds value to final production. In this group, the 
families bought some fresh fruits for pulp sale, counted as non-farm income, since it characterized trade and it was not originated from the family's own cultivation, which justifies the higher non-agricultural income of that group in relation to the others. Non-farming income is characterized by any income obtained outside the family production plot, whether through formal labor, general trade, labor, equipment rental, among others.

It is known that the total value generated by the production systems is not retained in the establishments since part of this value is converted out of the system in the form of salaries, taxes, fees, and others. Even in small proportions, most types have some income outside the establishment, due to the hiring of daily wages for activities of the crop (weeding, harvesting).

The bacurizeiro and fishing (T3) showed an added value of 9,640.00BRL /year, and non-farm income had the most significant contribution in the formation of total family income. This is because families of this type receive insurance, which contributes to the family organization.

The group that obtained the lowest value for the farm income was the one based on social security (T4). This income comes from the sale of bacuri fruits and pulp since this group did not have crop systems, with only adult bacurizeiro managed in the backyard as part of the composition of the family landscape.

Table 4. Economic results of Added Value, Farm Income, Non-Farm Income and Family Income, per family production systems type of the establishments studied in the Northeastern Pará and Marajó (Values in BRL)

\begin{tabular}{lcccc}
\hline Types & AV & FI & NFI & FI' \\
\hline T1 - Bacurizeiro and crops & $9,568.72$ & $8,611.84$ & $13,307.82$ & $21,919.67$ \\
T2 - Bacurizeiro and fruit & $23,140.33$ & $20,826.30$ & $19,069.20$ & $39,895.50$ \\
trees & & & & \\
T3 - Bacurizeiro and & $9,640.75$ & $8,676.68$ & $18,449.78$ & $27,126.45$ \\
fishing & & & & \\
$\begin{array}{l}\text { T4 - Governmental } \\
\text { transfers }\end{array}$ & $4,546.33$ & $4,091.70$ & $16,942.27$ & $21,033.96$ \\
\hline
\end{tabular}

Observation $\mathrm{AV}=$ Added Value; FI= = Farm Income; NFI = Non-Farm Income, FI' = Family Income.

The group that obtained the lowest value for the farm income was the one based on government transfers (T4). This income comes from the fruit sale since this group did not have any crop systems, with only adult bacurizeiro managed in the backyard as part of the composition of the family landscape. 


\section{IIMacrothink

Concerning the reproducibility of the production systems, it was found that, except for the type 2 system (bacurizeiro and fruit trees), the others are below the SRL line, equivalent to 12,181.00BRL, as it can be observed in Figure 1. SRL is the minimum income to meet basic household needs such as food, health, education, clothing, and eventually leisure (Dufumier, 2010).

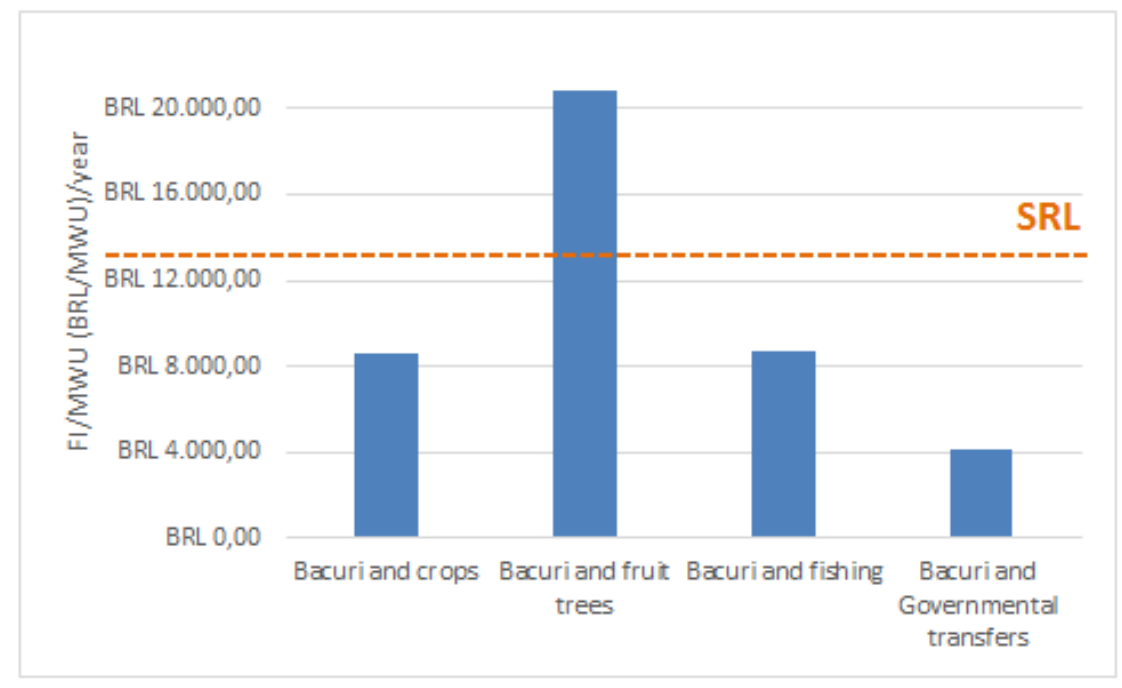

Figure 1. Economic evaluation of family production system type, relation between income per family labor

Only the predominant type in fruit trees (T2) exceeded the SRL line. Thus, it can be stated that diversification guarantees the economic sustainability of family production systems, as it allows income to be obtained throughout the year and the possibility of value aggregation, even if in primary forms such as the manual production of pulp for the local market. Groups that stayed below average of simple reproduction have external sources of income, which justifies their permanence in time. Dufumier (2010) argues that when a production system is below the SRL line, a collapse may happen (farmers sell the lots) or external income inputs may appear.

\subsection{Contribution of Fruit and Pulp to Family Income}

In order to carry out this evaluation, the income obtained from the sale of fresh fruits and pulp was considered. In the bacurizeiro and crop production system (T1), the annual contribution of the sale of fruit and pulp to the farm income was $29 \%$ and $13 \%$ for the total family income. For the bacurizeiro and social security group (T4), this participation was $96 \%$ and $14 \%$, respectively. 


\section{I Macrothink}

Journal of Agricultural Studies

ISSN 2166-0379

2020, Vol. 8, No. 4

Table 5. Share of fruit and pulp (\%) in Farm Income and Total Income of the family production system type in the study

\begin{tabular}{lcc} 
Types & Fruit an pulp share in FI (\%) & $\begin{array}{c}\text { Fruit and pulp } \\
\text { share in TI (\%) }\end{array}$ \\
\hline T1 - Bacurizeiro and crop & 28.97 & 12.77 \\
T2 - Bacurizeiro and fruit \\
trees
\end{tabular}

Observation. $\mathrm{FI}=$ farm income; $\mathrm{TI}=$ total Family income.

It is noted that the income produced by the sale of fruit or its pulp has great importance for the families living and their reproductive strategies. The participation of bacuri fruit and pulp in the farm income is quite significant, since it is a species that usually have only a maximum of four two-month harvest periods.

\section{Discussion and conclusions}

The results of the field research allowed the elaboration of four production systems typology (bacurizeiro and crops, bacurizeiro and fishing, bacurizeiro and fruit trees, and bacurizeiro and social security) performed by the mesoregions families of Northeastern Pará and Marajó. Economically, the only group that reached the minimum level of social reproduction was the bacurizeiro and fruit trees, demonstrating that the more diversified the families production, the higher is the economic return.

It was observed that the productive activities of crop production are insufficient to guarantee the social reproduction level of the families. Fishery-based production systems also proved to be inadequate.

The contribution provided by bacuri fruit and pulp is significant in all types of existing production systems, representing minimum average participation in farm income of $19.99 \%$ (and fishing). It is possible to state that the fruit and pulp sale is an essential strategy of social reproduction for small farmers in the Northeastern Pará and Marajó, mainly considering the current price that is relatively high in the local market.

It is important that further studies to be conducted within the scope of small producers in order to quantify the production of these invisible products. In this way, there will be a social and environmental valuation of this species, which has productive potential for generating 
jobs and income in the rural environment, contributing to the local development.

Few papers approach bacurizeiro intending to perceive the species and other non-timber forest products (NTFPs) as an integral part of the production system in Amazon (Medina \& Ferreira, 2003). It is necessary field studies whose objective is to rescue the knowledge of people who have been managing their areas with bacurizeiro and the importance they have attributed to the fruit. Thus, it is vital for the government to promote this activity through the provision of credit to small farmers for bacurizeiro management, supplying the need to hire labor for the first years of management. It is important as well to establish partnerships with research institutions such as Eastern Amazon Embrapa and universities in order to promote the farmers capacity to carry out the bacurizeiro management in a conscious, efficient and sustainable way. Through these partnerships, the government could offer organizational and entrepreneurial technological capabilities. With that communities can, through cooperatives, offer a higher quality end product and added value to the consumer, which would raise farm income and contribute to the development of the region.

\section{Acknowledgement}

The authors are grateful to Beatriz Cordeiro Costa and Isabel Valença for the English version revision of the article.

\section{References}

Brumer, A. et al. (2008). A elaboração de projeto de pesquisa em ciências sociais. In: Guazzelli, C. A.; Pinto, C. R. J. B. (Org.). Ciências humanas: pesquisa e método. Porto Alegre: UFRGS, p. 125-147.

Cavalcante, P. B. (1991). Frutas comestíveis da Amazônia. 5 ed.. Belém: INPA-CEJUP, 179p.

Dufumier, M. (2010). Projetos de desenvolvimento agrícola: manual para especialistas. Tradução Vitor de Athayde Couto. 2 ed. Salvador: EDUFBA.

Ferreira, M. S. do. (2008). Bacurizeiro (Platonia insignis Mart) em florestas secundárias: possibilidades para o desenvolvimento sustentável no Nordeste Paraense. 2008. 212 p. Tese (Doutorado) - Centro de Desenvolvimento Sustentável, Universidade de Brasília, Brasília (DF).

Garcia Filho, D. P. (1999). Análise diagnóstico de sistemas agrários. Guia Metodológico. Brasília: Projeto de cooperação Técnica INCRA/FAO, 65p.

Homma, A. K. O., Menezes, A. J. E., Carvalho, J. E. U. de, Matos, G. B. (2018). Manejo e plantio de bacurizeiros (Platonia insignis Mart.): a experiência no manejo e domesticação de um recurso da biodiversidade amazônica. Brasilia: Inc. Soc., 12, 48-57.

Marconi, M. A., Lakatos, E. M. (1996). Técnicas de pesquisa: planejamento e execução de pesquisa, amostragens e técnicas de pesquisa, elaboração, análise e interpretação de dados. 3 . ed. rev. aum. São Paulo: Atlas, 231 p.

Matos, G. B. (2008). Valorização de produtos florestais não madeireiros: o manejo de 
bacurizeiros (Platonia insignis Mart.) nativos das mesorregiões do Nordeste Paraense e do Marajó. 2008. 112f. Dissertação (Mestrado em Agriculturas familiares e desenvolvimento sustentável) - Programa de pós-graduação em Agriculturas Amaônicas, Núcleo de Ciências Agrárias e Desenvolvimento Rural, Universidade Federal do Pará, Belém.

Medina, G., \& Ferreira, M. S. G. (2003). Platonia insignis Mart. - Clusiaceae: o fruto amazônico que virou ouro. In: ALEXIADES, M. \& SHANLEY, P. (Edts.). Livelihoods, conservation and sustainability: case studies from Latin America. Bogor, CIFOR.

Menezes, A. J. E. A. (2010). Do Extrativismo à domesticação: o caso dos bacurizeiros (Platonia insignis Mart.) do Nordeste Paraense e Marajó. 2010. 196 p. tese (Doutorado em Ciências)- Faculdade de Agronomia Eliseu Maciel, Universidade Federal de Pelotas, Pelotas.

Menezes, A. J. E. A. et al. (2012). Do extrativismo à domesticação: o caso do bacurizeiro no Nordeste Paraense e Marajó. Belém: Embrapa Amazônia Oriental, 66p. (Documentos, 379).

Menezes, A. J. E. A. et al. (2016). Manejo de rebrotamentos de bacurizeiros (Platonia insignis Mart.): distribuição espacial e considerações tecnológicas dos produtores nas mesorregiões Nordeste Paraense e Marajó. Belém, PA. (Documentos) Embrapa Amazônia Oriental, $47 \mathrm{p}$.

Redin, E. (2011). Entre o produzir e o reproduzir na agricultura familiar fumageira de Arroio do Tigre/RS. 2011. 261 f. Dissertação (Mestrado em Extensão Rural) - Universidade Federal de Santa Maria, Santa Maria.

Vinuto, J. (2014). A amostragem em bola de neve na pesquisa qualitativa: um debate em aberto. Temáticas, Campinas, 22(44), 203-220.

Wünsch, J. A. (2010). Elementos conceituais para a representação de sistemas agrícolas. Pelotas (RS): Embrapa Clima Temperado.

\section{Copyright Disclaimer}

Copyright for this article is retained by the author(s), with first publication rights granted to the journal.

This is an open-access article distributed under the terms and conditions of the Creative Commons Attribution license (http://creativecommons.org/licenses/by/4.0/). 